of Manchester, where, except for a period of war service, he spent the years 1915-1920. His next three years were passed at Eton with Prof. R. Whytlaw. Gray, carrying out research on aerosols for the Chemical Warfare Committee. Since 1925 he has been in charge of the Textile Chemistry Laboratory of the University of Leeds, where he was appointed lecturer in 1925 and reader in 1937. Dr. Speakman has been awarded the Warner Memorial Medal of the Textile Institute, and three times he has been the recipient of the Research Medal of the Worshipful Company of Dyers. He has also served for a dozen years on the council of the Textile Institute, and on the Publications Committees of the Textile Institute and the Society of Dyers and Colourists. Under his direction, the Leeds Textile Chemistry Laboratory has attained a high and well-deserved reputation, and his new appointment will undoubtedly lead to still wider successes in his chosen field.

\section{Dr. R. G. S. Hudson}

DR. R. G. S. Hudsox has been appointed to succeed Prof. A. Gilligan as professor of geology in the University of Leeds. Dr. Hudson studied geology at University College, London, under Prof. E. J. Garwood. He later joined the staff of the Geological Department at University College and commenced research on the fauna of the Yoredale Series. He continued his interest in Carboniferous stratigraphy after his appointment in 1922 to the geological staff of the University of Leeds. The greater part of his work has dealt with the Dinantian and Namurian of Yorkshire especially with the relation between the various facies and faunal assemblages. He early demonstrated the unconformable junction between the Lower and Upper Carboniferous of Yorkshire; later, with Dr. G. H. Mitchell he described the geology of the Skipton anticline, and with the aid of various grants put down a boring in that area to the base of the Carboniferous. He has devoted attention to the Variscan orogeny and its control of sedimentation. His interest in the fauna of the Carboniferous has resulted in the description of new genera and species of corals such as Rylstonia, Rhopalolasma, and various species of Orionastrae. In 1931, Dr. Hudson was awarded the Wollaston Fund of the Geological Society and has served on the Council of that society. He has also been secretary of various committees of Section $\mathbf{C}$, British Association, and is now joint secretary of that section. Dr. Hudson has taken considerablo part in the organization of the geological societies in Yorkshire, and for some years has been editor of the Proceedings of the Yorkshire Geological Society and the Transactions of the Leeds Geological Society.

\section{Imperial Cancer Research Fund: New Laboratories}

THe new laboratories of the Imperial Cancer Research Fund were opened on June 27 (see also p. 41). Sir Humphry Rolleston, chairman of the Executive Committee, read a message of regret from Lord Halifax, president of the Fund, who at the last moment had found himself unable to attend. Lord Halifax said that all would appreciate that at the present time he is even more than usually subject to sudden and unavoidable calls on his time and that although he ought not, perhaps, to have agreed to open the new laboratories he had been particularly anxious to do so. Lord Halifax sent the notes which he had prepared for his speech, in which he reviewed the history of the foundation of the Fund and its progress. Ho referred to the many famous men, including Isord Lister, A. J. Balfour and Joseph Chamberlain, who helped the Fund and mentioned the policy of collaboration with all organizations at home and abroad which has been followed throughout the thirty-seven years of the Fund's existence. An address on "Scientific Aspects of Cancer Research" was delivered by Sir Frederick Gowland Hopkins, whose theme was the importance of laboratory effort in cancer research. Ho expressed his own faith that each increase in accommodation provided for skilled laboratory effort has never failed to be justified by its results. Sir Frederick described the distinguished past of the Fund and stated his confidence in a future of continued and eminent success. A vote of thanks to Sir Frederick was proposed by Sir Robert Hutchison, president of the Royal College of Physicians and seconded by NIr. Hugh Irett, president of the Royal College of Surgeons.

The laboratories, designed by Messrs. Lanchester and Lodge, occupy an open position on the Ridgeway at Mill Hill. The three-storied main building is built in T-form with a central staircase; the corridors, as a result, are short and well-lighted. A goods lift serves one wing which is devoted mainly to animal rooms, stores and service rooms. The library, offices, one large laboratory, a room for X-ray equipment, centrifuge room, workshops and stores are on the ground floor. The first floor comprises a large chemical laboratory with a smaller laboratory adjoining, five other private laboratories, photographic room, sterilizing room and animal rooms. 'The Director's office and laboratory are on the second floor, where there are three other laboratories, operating room, histological room and animal rooms. There is a cold room in the basement. The laboratories vary in size; some are suitable for one worker using simple equipment; others can accommodate two or three workers or bulky apparatus. Most of the rooms have one high and one low bench each with a sink supplied with mains pressuro water and hot water; gas and 5 and 10 amp. electric points are provided. The natural lighting, by large windows, is notably good. Artificial light is supplied by central pendants and supplemented, wherever required, by Anglepoise table lamps. Elaboration of structure and equipment has been avoided in favour of adaptability to varied needs. A detached animal house is designed for work with the larger animals; provision is made for the maintenance of fowls and the normal stock of rabbits and guinea pigs. Other animals, as required, are accommodated in out-houses. There are six acres of land available for pens, grazing and the cultivation of food crops for animals. 